$10-2-2017$

\title{
Consultation Paper on Tax Planning Using Private Corporations
}

Jinyan Li

Osgoode Hall Law School of York University, jli@osgoode.yorku.ca

Follow this and additional works at: https://digitalcommons.osgoode.yorku.ca/reports

Part of the Tax Law Commons

\section{Repository Citation}

$\mathrm{Li}$, Jinyan, "Consultation Paper on Tax Planning Using Private Corporations" (2017). Commissioned Reports, Studies and Public Policy Documents. Paper 199.

https://digitalcommons.osgoode.yorku.ca/reports/199

This Article is brought to you for free and open access by the Faculty Scholarship at Osgoode Digital Commons. It has been accepted for inclusion in Commissioned Reports, Studies and Public Policy Documents by an authorized administrator of Osgoode Digital Commons. 
Consultation Paper on Tax Planning Using Private Corporations

\author{
Submission by Jinyan Li* \\ *Professor of Law, Osgoode Hall Law School, York University \\ October 2, 2017
}




\section{Contents}

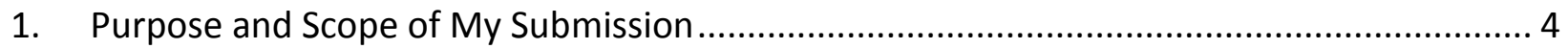

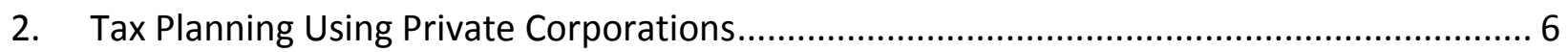

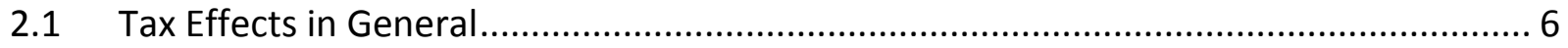

2.2 Issues Identified by the Minister............................................................................. 7

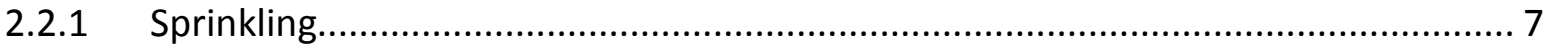

2.2.2 Holding passive investment portfolio inside a private corporation .......................... 7

2.2.3 Surplus stripping -converting income into capital gains......................................... 8

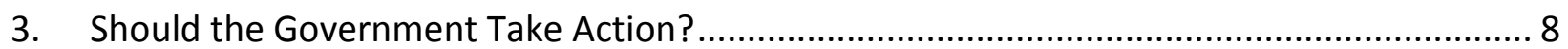

3.1 Progressive Taxation as Democratic Choices ................................................................ 8

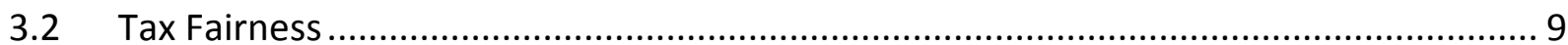

3.2.1 Ability to pay principle ………………………................................................. 9

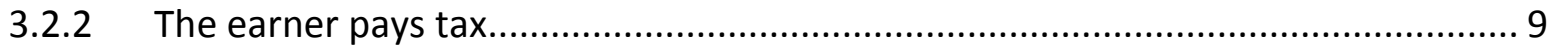

3.2.3 Gifting with after-tax income...................................................................... 10

3.3 Corporate Veil Does Not Negate Progressive Tax..................................................... 11

3.3.1 Freedom of incorporation and tax planning ......................................................... 11

3.3.2 Corporate tax backstops personal tax ………................................................ 12

3.4 Unintended Use of Tax Subsidies............................................................................. 12

3.4.1 Tax assistance to investment and risk taking .................................................... 12

3.4.2 Lower corporate tax rates as a tax subsidy ........................................................ 13

3.4.3 Capital gains and lifetime capital gains exemption ............................................. 14

4. General Comments on the Minister's Proposals ................................................................. 15

4.1 Ensuring Tax Fairness and Economic Growth ...................................................... 15

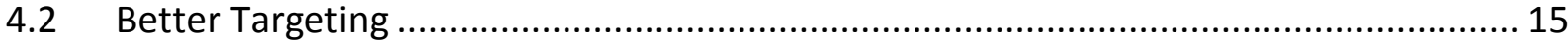

4.3 Protecting Personal Tax Base versus Preventing Unintended Use of Tax Subsidies ..... 16

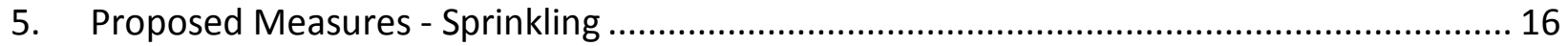

5.1 Proposed Measures................................................................................................... 16

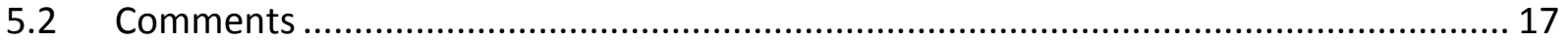

5.2.1 Alternative approach: Neutralize the "sprinkler" .............................................. 17

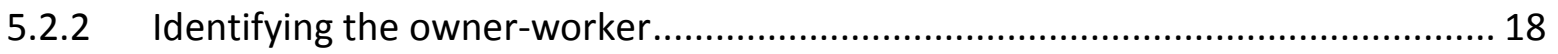

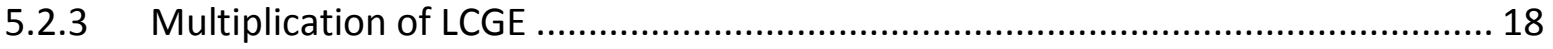




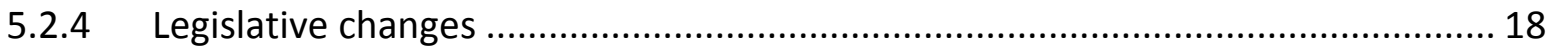

6. Contemplated Measures: Passive Investments........................................................ 19

6.1 Contemplated Measures............................................................................... 19

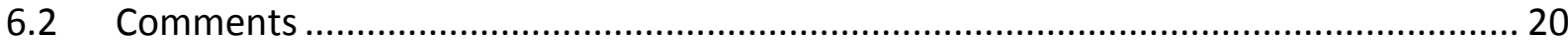

6.2.1 Alternative approach: removing the source of "free capital" for undeserving

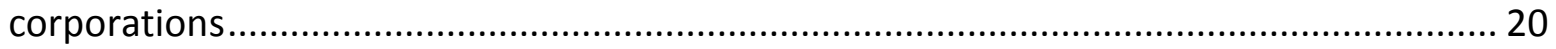

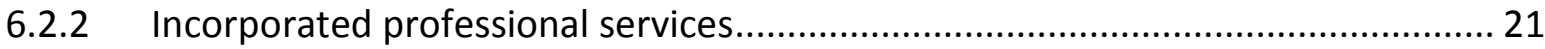

6.2.3 Passive investments by active business corporations ..................................... 22

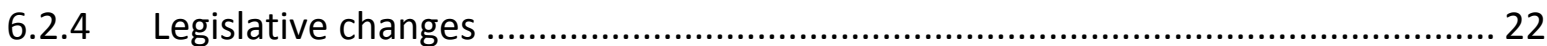

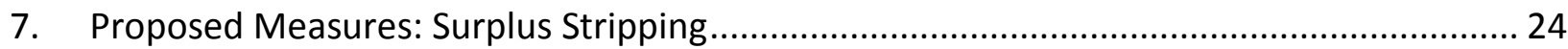

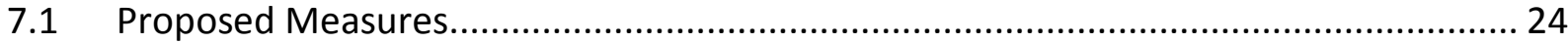

7.2 Comments on Inter-generational Transfers............................................................. 24

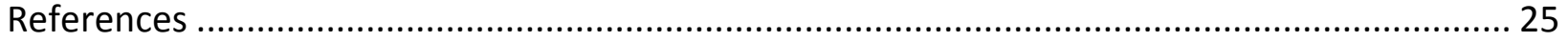




\section{Purpose and Scope of My Submission}

I am a tenured professor at Osgoode Hall Law School of York University, teaching and researching in the area of tax law. I am the lead author of Principles of Canadian Income Tax Law ( $9^{\text {th }}$ ed.) (Li, Magee and Wilkie, 2017) and International Taxation in Canada ( ${ }^{\text {rd }}$ ed.) (Li, Cockfield and Wilkie, 2014). I am also the lead editor of Income Tax at 100 Years (Li, Wilkie and Chapman, 2017). I am a member of Panel of Experts Reviewing Federal Tax Expenditures (the Expert Panel) (http://www.fin.gc.ca/access/tt-it/rfte-edff-eng.asp), but was not involved in drafting the consultation paper on Tax Planning Using Private Corporations (the "Consultation Paper").

I would like to comment on the Consultation Paper in terms of the nature and seriousness of the problems identified as well as the proposed solutions. My comments focus on fundamental issues of tax policy and tax legislation as opposed to the application of specific proposals to assumed facts or estimating the impact of the proposals.

I make these comments in my personal capacity as a concerned citizen, not as an employee of York University or a member of the Expert Panel. I have benefited from discussions with Robin Boadway and Scott Wilkie as well as from reading the Arnold Report (Canadian Tax Foundation, August 30, September 11 and 13, 2017). The views expressed below are those of my own.

I agree with the Consultation Paper that there are serious problems associated with using private corporations (or Canadian controlled private corporations or CCPCs) primarily for tax planning purposes. If left unaddressed, these tax planning strategies could enable some Canadians to opt out paying progressive tax on their personal income. That will be unfair. Since 1917, progressive taxation has been one of the means of achieving fairness in Canada and a hallmark of our democratic society. Progressive taxation is the collective bargain by all Canadians through the democratic process. Allowing some taxpayers to opt out undermines that bargain.

However, I have some concerns about the proposed solutions. I submit that the solutions to deal with the so-called "passive investment" problem and "sprinkling" problem can be better targeted, simpler and, arguably, more effective. I find the Minister's proposals regarding surplus stripping are generally fine, although some tweaking can make them better. 
My main submissions are as follows:

1. The Minister should proceed with legislative changes to prevent some individuals from nullifying progressive tax through the use of private corporations.

2. The reform measures should ideally strike a balance between the protection of fairness of the tax system and the legitimate concerns of small business owners about compliance burdens and the right to tax planning in order to achieve (but not over shoot) objectives that nevertheless, despite the form, would be consistent with fiscal objectives already discernible in the tax system.

3. To address the sprinkling problem, the Minister proposed to extend the "kiddie tax" rules to adults. I suggest an alternative to neutralize the "sprinkler" by re-directing the diverted income back to the owner-worker (or principal of the business, in the words of the Consultation Paper) whose efforts and entrepreneurship (as well as the capital) earned the sprinkled income. This is in line with the underlying principle of s.56(2).

4. With respect to a CCPC's passive investments, the core problem is the source of capital for investment, not the income from passive investments. Where the source of capital is the "free capital" resulting from having personal income taxed at a corporate rate ( $26.5 \%$ general rate or $15 \%$ small business rate in Ontario) as opposed to the top personal rate (assuming 53\% in Ontario), access to such free capital can be denied or restricted by taxing some measure of the income at top personal rate. There are generally adequate rules to treat CCPC's passive income earned from investing the free capital (i.e., s.123.3, refundable dividend tax on hand or RDTOH and integration), but inadequate rules on who is entitled to the free capital.

5. The targeted, undeserving income that generates "free capital" should be the kind of income the earning of which produces insignificant positive societal benefits in terms of economic growth or job creation. Examples are incorporated professional services that are, in essence, providing the services of the professional ("specified professional services"). Such income earned directly by the providers or indirectly through a CCPC should be treated the same from a tax policy perspective. The current tax system already does this in respect to personal services business (s.123.5) and specified investment business (s.123.3). The same approach can be extended to specified professional services.

6. I share the concern about the impact of the proposed surplus stripping rules on "genuine" intergenerational transfer of business and applaud the Government for soliciting views on this matter. 


\section{Tax Planning Using Private Corporations}

\subsection{Tax Effects in General}

Canadians are free to incorporate under either provincial law or federal law. A corporation has an independent legal personality. There are several tax implications of earning income through a corporation.

1) Separating the original owner from his/her income.

Taxpayer $X$ provides professional services to clients and is the earner of the professional fees. If $X$ incorporates $X c o$, owns all of the shares of $X c 0$, and provides services as an employee of Xco to clients, $X c 0$ receives the fees. The fees are now earned, technically, by $X c 0$, even though it is $X^{\prime}$ 's performance of services that generates the income.

2) Converting the character of income.

In the above example, if $X$ co pays dividends to $X$, dividends are income from property; if Xco pays a salary to $X$, the salary is income from employment; if $X$ sells some of his $X$ co shares for a value that reflects the after-tax earnings of $X c 0, X$ realizes a capital gain. In the absence of $\mathrm{Xco}, \mathrm{X}$ will just earn professional fees, typically as a form of business income or employment income.

3) Shifting personal income tax base to corporate tax base.

In the above example, in the absence of Xco, $X^{\prime}$ s professional fees are subject to personal income tax at progressive rates. By using Xco, the fees are subject to corporate tax at a flat rate, which is much lower than the top personal rate. The effect of using Xco is to shift the tax base from personal tax to a corporate tax, even though, it is X's services that generate the fees. In other words, using Xco achieves the conversion of personal income into corporate income coupled with unlimited deferral of the personal element of the tax that ultimately is meant to be payable.

4) Diverting income to related persons.

Xco's directing mind is $\mathrm{X}$; there is a complete identity of interest. There is no market discipline or exogenous accountability on or for the governance or management of Xco that can be introduced by having arm's length investors. As such, $X$ can have Xco issue different classes of shares to his family members and distribute dividends on different classes of shares. Even though Xco's profit is derived from X's performance of personal services, income from such services is diverted to other shareholders. The diverted income bears, at best, only corporate tax.

In the absence of Xco, diverting income to family members is subject to anti-splitting rules, such as s.56, s.74.1 and s.74.2, or s.120.4 (the "kiddie tax"). X can assign his income only after paying personal tax on the income. 


\subsection{Issues Identified by the Minister}

The Consultation Paper identifies three tax planning strategies: sprinkling, passive investments and surplus stripping.

\subsubsection{Sprinkling}

The Consultation Paper states that the sprinkling strategy is most likely used by higher income individuals, facing high personal tax rates. The amount of tax savings is determined by the difference between the tax rate for the actual earner and the "sprinkled" family member, as well as the number of family members.

For example, if X's tax rate is $53 \%$ and his child's tax rate is $20 \%$, diverting $\$ 100,000$ income to the child would save $\$ 33,000$ of tax for the family. In effect, through the use of Xco, X creates a "family-based" unit of taxation, while the tax system has been designed to tax each individual's income at progressive rates.

The Consultation Paper refers to research and commentary as evidence for supporting the claim that the ability to reduce the effective tax rate for personal income, including through sprinkling, is an important consideration in deciding whether to incorporate a business and how to structure ownership of a private corporation (at 19).

The above mentioned anti-splitting rules are inadequate in addressing some forms of sprinkling, such as diverting income to adult children.

\subsubsection{Holding passive investment portfolio inside a private corporation}

The Consultation Paper states at page 32 that "corporate income is taxed at lower rates than personal income, giving businesses more money to invest in order to grow their business, find more customers and hire more people." Where this additional money (capital) is used to acquire passive investments, owners of CCPCs have a tax advantage over other taxpayers.

For example, Taxpayer $X$ and Taxpayer $Y$ are in the same profession, providing services to clients. $X$ earns $\$ 100,000$ income through Xco; Xco pays tax at 15 percent; Xco has $\$ 85,000$ capital for investment. Taxpayer $Y$ provides her services without using a corporation and earns $\$ 100,000$ personally. Assuming Y pays tax at $53 \%$ on the $\$ 100,000$, she would have only $\$ 47,000$ capital for investment. The $\$ 38,000$ difference is the additional capital (which I refer to as "free capital").

The current tax law treats passive income earned by CCPCs similarly to that earned by individuals personally, but it does not deal with the advantages of having the extra free capital through the use of CCPCs. "Preferential tax rates for corporations were never intended to facilitate passive wealth accumulation, such as through passive investments." (Consultation 
Paper, at 39). The Consultation Paper shows that the extent of such tax advantage can be "very significant" (at 33-34).

\subsubsection{Surplus stripping -converting income into capital gains}

A corporation's surplus is "made up of its accumulated after-tax earnings and unrealized corporate value minus its liabilities." (Consultation Paper, at 55) Owners of CCPCs can extract corporate surplus by paying themselves a salary (which reduces the corporation's pre-tax income) or dividends (which is paid with after-tax earnings). Alternatively, the owners can sell their shares at prices that reflect the value of the corporation and realize capital gains.

Taxpayers prefer to receive capital gains because of the preferential tax treatment of capital gains: $50 \%$ of capital gains are taxable and up to $\$ 800,000$ can be excluded from income altogether (the lifetime capital gains exemption or LCGE).

When owners of private corporations sell their shares on the market and realize capital gains, even though they could have received dividends before selling the shares, tax law does not recharacterise the capital gains as dividends. The arm's length sale of shares is not regarded as

"surplus stripping". Surplus stripping targeted by the Consultation Paper is limited to stripping "through a series of self-dealing private corporation transactions" (Consultation Paper, at 15, emphasis added). In other words, the "seller" does not "genuinely" give up ownership of the business of the CCPC and retains "control" through non-arm's length arrangements.

The Consultation Paper states that the existing anti-surplus stripping rules in section 84.1 are inadequate in some cases. The CRA has mixed results in courts in challenging surplus stripping transactions under the existing s.84.1 and the GAAR where taxpayers extract corporate surplus as capital gains if the extracted surplus does not result in a capital gain eligible for a LCGE.

The Consultation Paper recognizes that a tightened-up s.84.1 may unfairly affect genuine intergenerational transfer of shares of a small business corporation to an adult child's corporation. It invites public input on this issue.

\section{Should the Government Take Action?}

I agree with the general convictions that motivate the Minister's proposals: the income tax system should be fair; tax subsidies in the form of lower corporate tax rates and preferential taxation of capital gains should be used as intended. I provide some elaboration below.

\subsection{Progressive Taxation as Democratic Choices}

Income tax was introduced in 1917 because it was a "fair form of taxation". (Campbell and Raizenne at 2:13). Since 1917, personal tax has been imposed at progressive rates. Progressive taxation is the primary means of achieving fairness based on the ability to pay principle. 
Although the level of progressivity has changed over the years, the Canadian democratic process has consistently confirmed the use of progressive taxation (Li and Wilkie).

"The nature of a country's tax system inevitably reflects the relative weight that society through its political institutions decides to place on different objectives and the extent to which tax instruments are explicitly or implicitly intended to achieve these objectives. As the eminent American jurist Oliver Wendell Holmes observed, taxes are the price we pay for civilization. It is not surprising then that many of the criteria commonly associated with identifying and devising good tax policy reflect notions of "fairness" (sometimes considered the glue of a democratic society) in the distribution of tax responsibilities." (Bird and Wilkie)

In the past, where some individuals try to opt out of progressive taxation through the use of legal facilities and strategies, tax law has counteracted with anti-avoidance rules. In the case of using CCPCs as vehicles of avoiding progressive taxation, the Government should take action to prevent this avoidance technique.

\subsection{Tax Fairness}

\subsubsection{Ability to pay principle}

Progressive taxation of personal income is generally considered fair because it is based on the "ability to pay" principle (Carter Commission). Ability to pay is generally measured by the amount of taxable income. An individual with more income not only pays more taxes, but also pay tax at higher rates. When two individuals earn the same amount of income, they are expected to pay the same amount of tax. This is considered fair because their ability to pay tax is the same.

If some individuals can opt out of progressive taxation in a manner unintended by tax law, tax law needs to react in order to protect the values and principles enshrined in progressive taxation. They reflect the values of Canadian society. Furthermore, if some individuals pay less tax through tax planning, other individuals would need to pay more to sustain the level of government spending or have their social benefits reduced.

The Government should be applauded for trying to improve tax fairness "by making sure that we all pay our fair share of taxes -with no exceptions." (Consultation Paper, page 4)

\subsubsection{The earner pays tax}

There is a basic principle underlying sections 2 and 3 of Income Tax Act -the earner of income pays tax. Section 2 says that income tax shall be paid on the taxable income of every person resident in Canada. Section 3 says that the "income of a taxpayer" is the taxpayer's income from, among others, incomes from office, employment, business and property. Although the Act does not further define "taxpayer's income", the legislative context indicates that the 
taxpayer is the person who earns the income from office or employment (i.e., performing personal services in the capacity of an employee or officer), who owns a business or who owns property.

Generally speaking, tax law defers to non-tax law for determining the legal relationships or transactions that give rise to income. This is sometimes referred to as the 'accessory principle'. For example, an employment contract determines who is the employee and how much remuneration is payable. An investment contract determines the return on investment made by the owner of capital. General laws (such as real estate law, intellectual property law and corporate law) establish the ownership of property.

When various manifestations of the private laws are used by the earner to deflect his or her income to another person (typically a related individual or controlled corporation), the Income Tax Act taxes the earner while respecting the validity of the legal arrangements for non-tax purposes. This is the case of the anti-splitting rules. Below are some examples:

1) If Mom owns a business and pays her 14-year old son a full-time salary for doing parttime work, section 67 denies Mom the deduction for "unreasonable salary" paid to the son in computing her business income. So, Mom cannot divert her business income to the child by over-paying him.

2) If Mom and her 14-year old son form a partnership to carry on the business, the share of son's income must be "reasonable in the circumstances" under section s.103.

3) If Mom asks her business clients to pay the money owed to her to her son, that money is deemed received by Mom (s.56(2)).

4) If Mom owns shares of a publicly traded company and gives them to her 14-year old son as a gift, any dividends received by the child on the transferred shares are taxable to Mom (s.74.1(2)).

Where CCPCs are used to divert income from the earner to his/her family members through sprinkling, progressive taxation is undermined. Amending the rules to defend their underlying principle and purpose is the right decision. That certain judicial decisions are relied on for the effectiveness of such arrangements is beside the point if forward looking change is warranted on the basis of the principles I outline.

\subsubsection{Gifting with after-tax income}

If sprinkling were allowed to nullify progressive taxation of the earner, another fundamental principle would be violated. That is the principle of gifting with one's after-tax money (capital).

Tax law does not discourage gifting among family members. However, it allows gifting generally with after-tax income (in large measure, this is the nub of the issues addressed by the 
Consultation Paper), not pre-tax income. Until tax is paid, the tax portion of a taxpayer's income does not belong to the taxpayer and is not available for the taxpayer's private use. The above anti-income diversion rules make this point. Even capital gains accrued to a property cannot be shifted by the owner to a related person without triggering tax on the accrued gains, unless tax law allows an exception (typically known as "rollover rules"). For example, if Mom gives her capital property to her 14-year old son for free, Mom is deemed to have sold the property for fair market value and realize capital gains for tax purposes (s.69(1)). If Mom is not allowed to give pre-tax income directly to family members, she should not be able to do so indirectly through using a corporation.

\subsection{Corporate Veil Does Not Negate Progressive Tax}

\subsubsection{Freedom of incorporation and tax planning}

Taxpayers are free to use corporations to minimize their taxes. Tax law encourages Canadians to use corporations to carry on business, contributing to the economy and job creation. There is a "sacred" judge-made principle - which may in fact be much less elastic and validating of planning behaviour than most in the tax community think - that taxpayers have the right to minimize their taxes:

"Every man is entitled if he can to order his affairs so that the tax attaching under the appropriate Acts is less than it would otherwise be." (IRC v. Duke of Westminster, Lord Tomlin).

This principle is well entrenched in Canadian tax culture, but it does not require us to stop thinking about whether it effectively creates an unlimited licence to benefit from what amount to self-generated tax expenditures. Even though the statutory General Anti-avoidance Rule (GAAR) enacted by Canadian Parliament in 1988 is commonly thought to be able to only attenuate this "principle" (Canada Trustco Mortgage Company v. Canada, 2015, SCC, para.13), it is not beyond question. The effectiveness of planning within context of the Income Tax Act always must be justified according to the underlying tenets of the Act as the Act reveals them. Taxpayers are free to use private corporations for tax planning purposes, but like all freedom it is not limitless or without purpose.

The evolution of tax law over the past 100 years indicates that a taxpayer's tax plan often prevails in court and result in tax benefit for the taxpayer. There may be a variety of reasons for this, which we should not assume necessarily reflect a principled validation of underlying fiscal or tax policy. But, Parliament has the "pen" to write legislative changes to neutralize the use of such tax plan on a moving-forward basis in order to ensure fairness of the tax system. The Minister's proposals are well within this tradition.

11 Jinyan Li, Submission on Tax Planning Using Private Corporations 


\subsubsection{Corporate tax backstops personal tax}

A corporation is a separate taxpayer and pays tax on its income. Since the inception of income tax in Canada, however, corporate tax has functioned as a withholding mechanism for personal tax and as means to backstop personal tax (Bird; Boadway; Ives Commission).

This means that progressive personal tax is paid by the individuals who earn income through a corporation: in the case of a salary, the owner-worker pays tax on the salary; in the case of dividends, the dividends are taxable to the shareholder with a credit for corporate tax -this is the integration principle. As explained in the Consultation Paper (at 34), "under the principle of tax integration, income earned by a corporation and distributed to shareholders as dividends should bear an amount of tax that is equivalent to what an individual earning the income directly would pay." The idea of "fiscal unity" underlies this integration principle (Wilkie). As long as corporate after-tax earnings are distributed to shareholders, the ultimate level of taxation is determined by the shareholder's top rate. As such, in essence, corporate tax functions as a withholding mechanism for personal tax on the shareholders.

The 1917 Income War Tax Act allowed the Minister to impute after-tax earnings of corporations to the shareholders for personal surtax purposes. At present, when a private corporation is essentially an incorporated employee or incorporated personal investment portfolio, sections 123.3 and 123.5 of the Income Tax Act impose additional tax on the corporation to match the top personal tax rate. In the absence of these additional taxes, skilled workers and capital owners could use private corporations to avoid paying progressive tax on their income.

The corporate veil can defer personal tax in circumstances where tax law encourages the use of corporations for business and investment purposes. Examples are public corporations and private corporations engaged in active business. Allowing tax deferral is meant as a tax subsidy.

\subsection{Unintended Use of Tax Subsidies}

\subsubsection{Tax assistance to investment and risk taking}

Tax subsidies are spending programs delivered through the tax system, known in tax jargons as "tax expenditures". Like direct spending programs, tax expenditures are, in effect, money spent by the government to achieve specific results for policy reasons. An example is encouraging investment, risk-taking and entrepreneurship. In evaluating tax expenditures, it is important to ask such questions as: Why is the spending decision made? What does the society (Canadian taxpayers in general) benefit from the tax spending? Is it effective?

If the government realizes that a specific tax subsidy is used in an unintended manner, the government, acting on behalf of all Canadians, is obligated to take action to address the 
problems. Two of the three issues identified in the Consultation Paper (i.e., passive investment and surplus stripping) can be analyzed as unintended use of tax subsidies.

\subsubsection{Lower corporate tax rates as a tax subsidy}

Taxing corporate income at a rate lower than the top personal rate creates an incentive for individuals to use corporations to earn income and accumulate income. As long as the accumulated income is not distributed to shareholders, personal tax is deferred. The value of this tax deferral depends on the difference between the personal rate and corporate rate and the amount of time that earnings are retained in the corporation. The amount of tax deferred is the free capital, a "gift" from the tax system to owners of the incorporated business.

Why allow lower corporate tax rates and tax deferral? There are several possible policy reasons. First, to prevent double taxation of income earned through corporations. Second, to make Canada competitive in attracting foreign investment. Most importantly, perhaps, the free capital was meant to be a tax subsidy to Canadians doing business through the corporate form. It was remarked by the Ives Commission in 1945 (at 65):

"It is undoubtedly true that the development of the Canadian economy would not have achieved its present state without the facility of conducting business under a corporate structure, separate and distinct from the shareholders of the corporation."

The corporate form presumably enables Canadians to start new business and expand business through raising capital from the public, thereby creating jobs and contributing to economic growth. Through allowing the use of "free capital" the tax system promotes economic growth that benefits Canadians as a whole. Again, Ives Commission stated (at 65):

"Furthermore, had it not been impossible under the tax law for corporations to retain some part of their earnings for contingencies and natural growth and expansion there could not have been the development of business in this country which has taken place in the past twenty-five years."

The Consultation Paper mentions at page 32 that corporate tax rates are lower than personal tax rates, "giving businesses more money to invest in order to grow their business, find more customers and hire more people." In addition, "small businesses" are perceived to suffer from market failures in raising the necessary capital and, thus, receive additional tax subsidy by paying tax at even lower rate (Benson, at 13-14; Dachis and Lester;). Businesses and investments are presumed to generate societal benefits. By receiving the tax subsidy, owners of incorporated businesses are expected to generate societal benefits, not to use the corporate form to primarily avoid progressive taxation of their income.

To buttress the intention of the tax subsidy, private corporations earning personal services business and passive investment income do not qualify for the lower rates. The Minister's 
proposal to remove the tax subsidy in the case of CCPCs using the tax subsidy for unintended passive investments is defensible in tax policy.

\subsubsection{Capital gains and lifetime capital gains exemption}

Capital gains are treated differently from earned income or income from capital because only $50 \%$ of capital gains are taxable as income. Among the primary reasons for partial taxation of capital gains are encouraging entrepreneurship, risk-taking and economic efficiency in preventing the lock-in effect and bunching effect (Clements et al; Mintz). Capital gains became taxable in 1972 for another, lesser known, reason - ensuring accumulated corporate earnings are taxable in the hands of shareholders when they strip the earnings from sale of shares (Wilkie).

Capital gains from the sale of qualifying small business corporation shares (typically a private corporation carrying on active business in Canada), qualifying farming or fishing property or shares of farming or fishing corporations are "exempt" from tax up to a maximum amount set by law for an individual's lifetime. The 1985 Budget that introduced the LCGE states at page 3:

"The budget proposes a major initiative to encourage risk-taking and investment in small and large businesses and to assist farmers by providing a cumulative tax exemption for capital gains up to a lifetime limit of $\$ 500,000$. This change will support equity investment and broaden participation by individuals in equity markets. In addition, it will improve the balance sheets and financial health of Canadian companies. It will provide a tax environment that is more conducive to high technology companies raising capital. It will encourage individual Canadians to start new businesses and will help small businesses grow."

As well, it was suggested that the LCGE was intended as a mechanism to help owners of small businesses and farmers to save for retirement in addition to the usual amounts available to taxpayers in retirement savings programs, such as RRSPs (Mintz and Wilson). The 1996, the Technical Committee on Business Taxation (Mintz Committee Report, ch.7) recommended a rollover of capital gains into RRSPs for farmers and small business owners.

Using private corporations tax planning strategies to convert dividends or salary to capital gains or to multiply LCGEs in circumstances described in the Consultation Paper achieves tax results that are not intended. The Minister is correct to introduce measures to counteract such strategies. 


\section{General Comments on the Minister's Proposals}

\subsection{Ensuring Tax Fairness and Economic Growth}

To ensure fairness, any unintended tax benefits arising from the use of CCPCs should be eliminated to the extent possible. However, very rarely, tax reform recommendations can effect exact equity or exact justice.

It is important that tax measures do not unnecessarily impede business initiatives and risktaking. The approach of the Ives Commission (page 51) seems to be wise and relevant to the present debates:

"Our objective has been to provide a method that will not only leave the Private Company in a healthy condition but enable it to pay to the Government as nearly as possible the aggregate amount of income tax that would have been paid if the Company had made an annual distribution to its shareholders, and also bearing in mind the value of encouraging the establishment of new companies."

Small businesses play an important role in the Canadian economy. According to Key Small Business Statistics - June 2016 ((http://www.ic.gc.ca/eic/site/061.nsf/eng/h_03018.html) published by the Government of Canada:

As of December 2015, the Canadian economy totalled 1.17 million employer businesses. Of these, 1.14 million (97.9 percent) were small businesses, 21,415 (1.8 percent) were medium-sized businesses and 2,933 (0.3 percent) were large businesses. As of 2015, small businesses employed over 8.2 million individuals in Canada, or 70.5 percent of the total private labour force. By comparison, medium-sized businesses accounted for 19.8 percent ( 2.3 million individuals) and large businesses accounted for 9.7 percent (1.1 million individuals) of the private sector workforce.

\subsection{Better Targeting}

Keeping in mind the balance between ensuring tax fairness and providing tax assistance to small businesses that generate societal benefits, the proposed measures should target as closely as possible those corporations that enjoy the tax assistance without producing the societal benefits.

Ideally, if less than 10 per cent of CCPCs would be affected by the passive-investment proposals (Globe \& Mail, Sept.28, 2017, A17), the remaining 90 percent of CCPCs should not be given any reasons to worry about the proposed measures. If incorporated professional services are the main issue, they should be specifically targeted. Without more pinpointed targeting, people may have reasons to cry things like: "Morneau is killing small business"! (Globe \& Mail, Sept.28, 2017, A4). 


\subsection{Protecting Personal Tax Base versus Preventing Unintended Use of Tax Subsidies}

Tax planning using CCPCs has given rise to two kinds of tax policy questions: how to protect the personal tax base through neutralizing the diversion of income away from the owner-worker; how to prevent unintended use of tax subsidies, such as lower corporate tax rates and the LCGE.

In order to prevent income diversion through sprinkling, it is critical to determine the ownerworker who earns the income in the first place. Such earner should be taxed on the income. It is less important to whom the earner shifts the income.

In order to prevent unintended use tax subsidies, it is critical to define the intended use. For example, if lower corporate tax rates were intended to encourage investment in business, then corporations that do not require, by nature, investment in assets or workforce should not be entitled to the lower rates. Also, if the lower corporate rates were not intended to subsidize doctors to save for maternity leave or top up their billable fees from provincial governments, then such issues should have no bearing on the debates about whether incorporated medical services should receive the tax subsidy. Perhaps a new tax subsidy could be created to subsidize doctors, but that is a different tax policy debate.

Similarly, if the LCGE was intended to benefit taxpayers who owned and operated small businesses, a less than two-year-old baby (see Pellerin v. R.) should not qualify for the LCGE.

\section{Proposed Measures - Sprinkling}

\subsection{Proposed Measures}

To address the sprinkling issue, the Minister proposes to extend the existing TOSI or kiddie tax to adults in certain circumstances. Under the proposal, dividends and other amounts received from a business by an adult family member of the principal of the business will be taxed at the top personal rate, unless a reasonableness test is satisfied. Reasonableness is based on the contributions made by the family member to the business. The test is stricter for 18-24 year olds. The scope of "sprinkling" is extended to cover "connected individuals" who may be arm's length persons and "compound income" (income earned from investing the sprinkled income).

To prevent the multiplication of claims to the LCGE, the Minister proposes to tighten eligibility for the exemption: the exemption is not available in respect of gains accrued before a taxpayer attained age 18, accrued to property held by a trust (typically a family trust) or included in TOSI. A reasonableness test is proposed, which would be the same as that for the proposed TOSI rules.

16 Jinyan Li, Submission on Tax Planning Using Private Corporations 


\subsection{Comments}

\subsubsection{Alternative approach: neutralize the "sprinkler"}

The sprinkling problem goes to the heart of the design of the tax system as it enables the income earner to nullify progressivity of personal tax. That offends the basic bargain made by Canadians through the democratic process in the past 100 years.

The current law adopts two approaches to remove the tax benefits of income shifting:

a) negative rules, such as the kiddie tax (TOSI), which deems the recipient not to have earned the income and taxes it at the top rate, which would have been applicable to the original earner;

b) positive rules, such as the attribution rules and indirect payment rule, which deems the diverted income to be earned by the original earner.

The Minister's proposed rules target the sprinkled, not the origin of income that is sprinkled. In other words, the Minister's proposal focuses on the family members who, in private law, receive dividends, but in fact, did not contribute to the earning of the underlying income.

I find the proposed TOSI rules complex. A somewhat simpler alternative is to neutralize the tax effect of the sprinkler by imputing a reasonable rate of return to each shareholder's paid-up capital and attributing the rest of distributions as the owner-worker's income. Once the workerworker is determined under a reasonableness test, all income of non-workers above the imputed rate of return on capital is attributed to that worker. This alternative would be simpler than the extended TOSI rules as it would not need to define the "scope of sprinkling", that is, "connected individuals" and "compound income."

My proposal is inspired by a similar approach in Norway and Sweden, both of which have adopted a dual income tax system. In such dual income tax system, it is critical to distinguish between income from labour and income from capital because progressive rates are applied to only labour income. In general, private corporations earn income through primarily the combination of labour of the owner-worker and capital. Once capital is rewarded with a reasonable rate of return, the rest of corporate income is deemed to be earned by the efforts of the owner-worker. If the owner-worker does not remunerate himself/herself with a salary (which is subject to progressive taxation) and instead distributes corporate earnings in the form of dividends, the dividends are taxed as labour income. (Genser; Lodin; Matheson and Kollbeins; Lodin; Milligan; Sørensen)

My proposal is based on the existing attribution rules and indirect payments rules which recognize the actual owner of income. The sprinkling (the corporate form and different classes of shares) is simply a means of diverting income and its effect should be ignored for tax

17 Jinyan Li, Submission on Tax Planning Using Private Corporations 
purposes. The sprinkling serves the same function as a "transfer of property" for attribution rules purposes or "assignment" for indirect payment rule purposes. Shareholders who have contributed capital should earn a reasonable rate of return. The idea of imputing a reasonable rate of return to capital is used in tax law already.

My proposal would apply to all CCPCs, not just those earning income from providing professional or personal services. The reason for that is income diversion violates the principle of progressive taxation, irrespective of the nature of business of the corporation. Of course, if the tax deferral is removed for specified professional services corporations, the tax benefit is reduced for sprinkling of shares of such corporations.

\subsubsection{Identifying the owner-worker}

It is challenging to craft legislative rules to define "owner-worker". The reasonableness test in the Government proposed TOSI rules can be used. The focus is on the income-earning factors in the corporation, i.e., labour, capital and risk-taking. This is a factual determination. Tax law has used such approach in preventing income diversion. Examples are section 67 (deduction of reasonable amounts), section 103 (reasonable sharing of partnership income), and section 247 (transfer pricing).

In defining "owner-worker," there is no need to distinguish workers based on their age. Age is an arbitrary threshold and an odd fit in a "facts-and-circumstances" determination. The CRA could be encouraged to develop guidelines for taxpayers and CRA auditors, but this type of factual determination is ultimately left to the courts.

\subsubsection{Multiplication of LCGE}

Multiplication of LCGE is a derivative of sprinkling. Given the intended purpose of the LCGE, this tax subsidy should be given to those involved in the business, i.e., owner-workers. Any nonarm's length shareholders should be denied of this tax subsidy unless they are owner-workers. Any capital gains realized by non-workers should be attributed to owner-workers. In other words, the same anti-income diversion rule should apply to dividends as well as capital gains.

\subsubsection{Legislative changes}

Instead of amending s.120.4 and s.110.6, I would propose to amend subsection 56(2) along the following lines: a) To deem any dividends or capital gains of a shareholder who is a child, spouse or other non-arm's length persons of an owner-worker of a corporation whose shares were held by such shareholder to be dividends or capital gains of the owner-worker to the extent that amount of dividends exceeds an imputed amount of return to the paid up capital of the shareholder; and b) Whether an individual is an owner-worker of a CCPC is based on a reasonableness test.

18 Jinyan Li, Submission on Tax Planning Using Private Corporations 


\section{Contemplated Measures: Passive Investments}

\subsection{Contemplated Measures}

Instead of proposing legislative measures, the Minister expresses intention to impose a nonrefundable tax on passive investment income and dividends where the source of that investment is low-taxed corporate income and to align the treatment of dividends paid out of the corporation's passive income with the source of the funds that generate the income. The goal is to eliminate the tax benefit of using low-taxed business income of corporations to earn passive income while maintaining the integration system and the lower corporate tax rate on business income.

In order to determine the source of capital used to earn passive income and the tax treatment of dividends paid from passive investment income, two broad methods "are being contemplated": the apportionment method and the alternative method (elective method). The apportionment method is described on page 47 of the Consultation Paper as follows:

"One such method would involve an apportionment of annual passive investment income that would be based, going forward, on the corporation's cumulative share of earnings taxed at the small business rate and the general rate, as well as amounts contributed by shareholders from their after-tax income. This would translate into three possible tax treatments for these amounts when distributed as dividends -eligible dividends, non-eligible dividends, or dividends that would be received tax-free at the shareholder level."

The apportionment method involves establishing three tax pools: general rate income pool, lower rate small business income pool and shareholders' contributions pool. Dividends paid out of different pools are treated differently at the shareholder level.

As an alternative to tracking under the apportionment method, private corporations would be subject to a default tax treatment unless they elect out. The default treatment would subject passive income earned in the corporation to non-refundable taxes at rates equivalent to the top personal tax rate and dividends distributed from such income would be treated as "noneligible" dividends. This method would assume that the passive income is funded using earnings taxed at the small business rate. Corporations whose funds were not taxed at the small business rate could be allowed to use the elective method - the corporation would pay additional non-refundable taxes on passive income, and would treat dividends paid out from passive income as eligible for the higher dividend tax credit rate. 
It seems that the mischief addressed is the lower-taxed corporate income being used to fund passive investments. However, the contemplated measures target the income from passive investments, not the source of capital for investments.

\subsection{Comments}

I find the suggested measures to be too broad, complex and as such, would likely fail to address the root of the problem. They are also not sensitive to business sector differences, and the consequently the possibility that at least to some extent the tax expenditure entailed by deferred tax of business income can be justified according to principles found elsewhere in the Income Tax Act. The Consultation Paper does not adopt an explicit tax expenditure analytical framework but it should, at least to provide directional guidance.

I propose to narrow the target to CCPCs that do not deserve the tax subsidy (i.e., lower corporate tax rates and use of free capital) and deny the subsidy so that corporate income is taxed at personal rate. This proposal is similar to the current treatment of corporations earning personal services business income and specified investment business income. There is no need to change the dividend system. As such, my proposal involves minimal changes to current scheme of taxing private corporations.

\subsubsection{Alternative approach: removing the source of "free capital" for undeserving corporations}

In 1972, a refundable tax in respect of ineligible investments was introduced, but was retroactively repealed. It was considered "complex and difficult". Also, the Minister of Finance noted in 1972 that "these small corporations which enjoy the benefit of the lower rate of tax will, in fact, use these savings to expand their businesses, to improve their technology and to create more jobs for Canadians" (Consultation Paper, at 41). The Consultation Paper notes at page 41 that "many business do exactly that" today.

The undeserving corporations are, therefore, those that use corporate earnings for other purposes, such as holding passive investments. Since it is difficult to establish precisely the investments of each private corporation every year, it is reasonable to assume that corporations whose businesses need capital to expand or hire more employees deserve the tax subsidy. Corporations whose source of income is primarily the labour of the owners have limited room for expansion are undeserving of the subsidy.

In the case of undeserving corporations, the root cause of the problem is the lower corporate tax rate (not just the small business rate) as compared to top personal rate. To deal with the problem, the entire benefit of lower corporate rates should be eliminated for undeserving corporations and their income should be taxed at the top personal rate. Denying the existence of free capital is "easier" and "simpler" than taxing passive investment income derived from 
such free capital. By denying the free capital, owners of undeserving CCPCs would be put on the same footing as owners of unincorporated businesses.

\subsubsection{Incorporated professional services}

The nature of business is a key factor in qualifying for the tax subsidies (lower rates and the LCGE). Active business involves workers, capital, and risks. It is common for business owners to use the corporate form in order to benefit from limited liability protection, opportunities for raising capital and sharing risks with other investors. Active businesses are deemed important to the Canadian economy and generate societal benefits. Incorporated personal services or incorporated investment portfolios are deemed not to generate sufficient societal benefits because the source of income is the owner's labour or capital. They do not create jobs for Canadians and do not, presumably, require the use of corporate form to expand. Therefore, these two types of businesses are taxed at top personal rates.

In the case of incorporated professional services, the nature of the business is providing professional services. The corporate form does not change the nature of the economic activity or for that matter a professional's personal accountability for it as clients receive services only from the licensed professionals. Professional corporations are not like general business corporations, even under non-tax law. For example, the Ontario Business Corporations Act (OBCA) stipulates that: a) professional corporations may not carry on a business other than the practice of the profession and related or ancillary activities; b) shares shall be owned by one or more members of the same profession; and c) the corporate form does not necessarily or typically offer limited liability to shareholders of professional corporations in respect of the professional services those shareholders provide as the incorporated professionals. A professional corporation cannot expand its business by hiring non-professionals. The source of income of such corporations is the professional's labour. Professional corporations are used primarily for tax purposes. (Baron; Krishna; Wolfson and Legree).

Professional services corporations do not carry on the type of business that generates the same kinds and scope of desired societal benefits qualitatively or as public economists would measure them in relation to measures of economic growth. In law, professional services corporations cannot use the after-tax earnings for business expansion or hiring more workers in the same way or typically with the same effect as non-professional businesses. Their owners tend to treat (and justify) professional corporations as private savings vehicles, arguing that they make-up for a lack of access to other deferred savings vehicles offered by the Income Tax Act that would allow them save for retirement. There is substantial doubt whether these corporations should qualify for the tax subsidy attendant on incorporation, and in principle their income should be taxed the same as if it were earned directly by the earners (i.e. professionals).

21 Jinyan Li, Submission on Tax Planning Using Private Corporations 
On the other hand, if a professional services corporation carries on an active business in a manner that is no different from other non-professional services businesses (such as hiring workers or investment in business assets), it should be treated like an active business corporation. Careful legislation is required to draw the line between a specified incorporated professional services business and an active business carried on by a taxpayer who happens to be a professional.

\subsubsection{Passive investments by active business corporations}

Active business corporations receive the benefit of temporarily free capital. Even without empirical validation it is expected that most of them likely will use the free capital in their business operations (which may include providing for reasonable present and post-retirement compensation to their "proprietors") in turn generating societal benefits. In principle, that is the expectation, and for many it would seem the reality. Even if some corporations make passive investments, it may make sense to allow some flexibility and not to impose additional tax on passive investment income for the following reasons:

a) Passive investment income is already subject to an additional refundable tax under s.123.3 unless the income pertains to or is incidental to an active business.

b) Any rules that require annual tracing of investments would be difficult to enforce and costly to comply with; and

c) Most importantly, unless the rules apply to all corporations, CCPCs and non-CCPCS, they would discriminate against CCPCs. The free capital is available to both public corporations and CCPCs. The difference lies only in the amount of the free capital: in Ontario, \$26.5 per \$100 income (53\% - 26.5 \%) for non-CCPCs and \$38 per \$100 income (53\%-15\%) for CCPCs. The same principle should apply to all corporations.

\subsubsection{Legislative changes}

As an alternative to the Minister's measures, I propose to tax incorporated professional services income at the top personal rate, thereby removing the tax subsidy and make no changes to the taxation of investment income except to ensure that the same income is not excessively taxed because of incorporation.

The advantage of the alternative approach is to improve tax fairness without creating significant complexity. The tax on incorporated professional services can be non-refundable (similar to the tax on personal services business under s.123.5) or refundable (similar to the tax on specified investment income under s.123.3). In either case, it will not affect the dividend and integration system. There would be no need for the corporation to track the source of funds for investments. The problem of using CCPCs as private investment vehicles is addressed at its root cause.

22 Jinyan Li, Submission on Tax Planning Using Private Corporations 
My proposal would require some legislative changes, mostly in sections 123.3, s.125, and s.129:

1. Section 123.3 would be amended, as and to the extent this would be necessary allowing for the scope of what is a "business", by extending the current rule to professional services business income so that such income is taxed at the top personal rate if the corporation does not pay dividends. This tax could be refundable when dividends are paid, using the existing RDTOH (refundable dividend tax on hand) mechanism in subsection 129(2) and integration system.

2. As an alternative, section $\mathbf{1 2 3 . 5}$ would be amended to tax incorporated professionals as incorporated employees.

3. Subsection 125(1) would be amended to exclude professional services business income from being eligible for the small business deduction.

4. Adding a definition in subsection 125(7) for "specified professional services business":

- A "specified professional services business" could be defined to refer to any services that must be performed by a licensed professional and workers are hired to assist the professional in providing the professional services.

- It could be buttressed by a "fewer than five full-time employee per professional" test. It would be similar to that in the "specified investment business" in subsection 125(7) or the Quebec test (Godbout Commission), but applied against each professional in order prevent multiple professionals form a corporation that hires more than five full-time employees.

5. Adding a definition in subsection 125(7) for "specified professional services income":

- $\quad$ This definition will include any income from a specified professional services business;

- It will deem any amounts received by a private corporation from an associated corporation as "specified professional services income" if the amounts are deductible by the payer in computing its specified professional services income. Typical amounts would be fees for management and other services, rent, royalties or interest. This rule would be similar to the character preservation rule in s.95(2)(a). It would prevent taxpayers from shifting this type of income to an associated company (such as a management company owned by a non-arm's length person) and transforming the character of the income into services fees or property income.

The above proposal is premised on treating an incorporated professional similarly to an unincorporated, self-employed professional. It does not prevent incorporated professionals from paying themselves and their family members remuneration for work done so that the earned income can qualify for contributions to RRSPs, Employment Insurance (including maternity leave), and the Canada Pension Plan. The professionals and their family members 
who have earned income can also contribute to TFSA, like other taxpayers. The bottom line of my proposal is to tax professionals the same whether their income is earned directly or indirectly through a corporation.

\section{Proposed Measures: Surplus Stripping}

\subsection{Proposed Measures}

The Government proposes to amend s.84.1 and to introduce a separate anti-stripping rule. Draft legislation is provided for comments. The Government invites views and suggestions on whether, and how, to better accommodate genuine intergenerational business transfers.

\subsection{Comments on Inter-generational Transfers}

I have no comments on the proposed surplus stripping measures.

I agree that the issue of intergenerational transfer of business requires further consideration. The issue arises in the context of surplus stripping because of the differential treatment of intra-family transfers and arm's length transfers: the amended s.84.1 would apply to the former, but not the latter. The outcome would be unfair if the intra-family transfer is a "genuine" transfer of equity ownership of a family business from one generation to another, as opposed to arrangements that were designed to primarily convert taxable dividends into capital gains. It is challenging to come up with legislative rules to draw the line between "genuine" intergenerational transfers and stripping transactions. The American approach is certainly worthy of some consideration.

In light of the policy objectives of the LCGE, which includes assisting owners of small businesses to save for retirement, one of the relevant factors in the line-drawing exercise may be whether the existing owner-manager is retiring from the business. If retirement is the reason for the transfer, then up to the specified limit for the LCGE can be exempted from the application of s.84.1. This can be achieved through a deeming rule like s.93 (to deem the recharacterised dividends under s.84.1 to be capital gains for LCGE purposes) or incorporating the LCGE limit in s.84.1.

Like the sprinkling proposals, the key is to ensure that the person claiming the LCGE is the individual whose efforts and entrepreneurship created the value of the shares.

The Government may go one step further in facilitating intergenerational transfers of business by extending the option of rollover in the event of death to inter-vivos transfer of farming and fishing businesses. 


\section{References}

1985 Budget, Tabled in the House of Commons by the Honourable Michael H. Wilson, Minister of Finance, May 23, 1985) http://www.budget.gc.ca/pdfarch/1985-pap-eng.pdf

Baron, "Selected Considerations in the Use of Professional Corporations" (2013) 61:4 Canadian Tax Journal 1167

Benson, Budget Speech, 1971

Bird, "Why Taxing Corporations?" Working Paper 96-2 prepared for the Technical Committee on Business Taxation

Bird and Wilkie, "Tax Policy Objectives" in Tax Policy in Canada (Kerr, McKenzie, and Mintz, eds.) (2012)

Bird and Wilson, “The Corporate Income Tax in Canada: Does Its Past Foretell Its Future?" (2016)

Boadway, "The Canadian Corporate Income Tax at 100 Years of Age: Time for a Change" in Income Tax at 100 Years: Essays and Reflections on the Income War Tax Act (2017) (Li, Wilkie and Chapman, eds.) 9:1

Carter Commission, Report of the Royal Commission on Taxation, vol.3 (1966)

Campbell and Raizenne, "The 1917 Income War Tax Act: Origins and Enactment" in Income Tax at 100 Years: Essays and Reflections on the Income War Tax Act (2017) (Li, Wilkie and Chapman, eds.), 2:1

Clements et al, "The Economic Costs of Capital Gains Taxes in Canada" in Capital Gains Tax Reform in Canada: Lessons from Abroad (2014)

Dachis and Lester, "Small Business Preferences as a Barrier to Growth: Not so Tall after All" (C.D. Howe Institute, 2015)

Dolson, “Policy Forum: Personal Services Businesses -A Two-sided Policy Problem" (2015) 63:3 Canadian Tax Journal 705

Genser, "The Dual Income Tax: Implementation and Experience in European Countries" (Ekonomski Pregled, 57 (3-4) 271-288 (2006)

Godbout Committee, Final Report of the Québec Taxation Review Committee (2015)

Ives Commission, Report of the Royal Commission on the Taxation of Annuities and Family Corporations 1945

Krishna, "Use and Abuse of Professional Corporations" (2016) 27:3 Canadian Current Tax 21 
Li and Wilkie, "Celebrating the Centennial of the Income War Tax Act, 1917: The Future Seen by the Light of 100 Candles" in Income Tax at 100 Years: Essays and Reflections on the Income War Tax Act (2017) (Li, Wilkie and Chapman, eds.), 1:1

Lodin, The Making of Tax Law: The Development of Swedish Taxation (2011)

Matheson and Kollbeins, "Allocating Business Income between Capital and Labor under a Dual Income Tax: The Case of Iceland" (IMF, WP/12/263, 2012)

Milligan, "Why small business taxation does need fixing" Maclean's Magazine. September 10, 2015

Milligan, "Tax Policy for a New Era: Promoting Economic Growth and Fairness" (C.D. Howe Institute, 2014)

Mintz, “Capitalizing on Cuts to Capital Gains Taxes" (CD Howe Institute, February 17, 2000)

Mintz Committee, Report of the Technical Committee on Business Taxation (1998)

Pellerin v. R. 2015 TCC 130

Sørensen, "Dual Income Taxation: Why and How?" (CESifo Working Paper No. 1551 Category 1: Public Finance, September 2005)

Sørensen, Neutral Taxation of Shareholder Income: A Norwegian Tax Reform Proposal (CESifo Working Paper No. 1036 Category 1: Public Finance, September 2003)

Wilkie, "Three Spirits of Canadian Corporate Income Tax: The Relic, the Remnant, and the Reflection" Income Tax at 100 Years: Essays and Reflections on the Income War Tax Act (2017) (Li, Wilkie and Chapman, eds.), 8:1

Wilson, "Canada's Corporate Income Tax: The First Ten Years (1917-1927)" in Income Tax at 100 Years: Essays and Reflections on the Income War Tax Act (2017) (Li, Wilkie and Chapman, eds.) 7:1

Wolfson and Legree, "Policy Forum: Private Companies, Professionals, and Income Splitting-Recent Canadian Experience," (2015) 63:3 Canadian Tax Journal 717

Wolfson, Veall, and Brooks, "Piercing the Private Veil: Private Corporations and the income of the affluent." https://uwaterloo.ca/school-of-accounting-and-finance/sites/ca.school-of-accountingand-finance/files/uploads/files/wolfson-brooks-veall___incomes_of_affluent.pdf. 